\title{
Sistem Reproduksi Parkit (Melopsittacus undulatus) Jantan dan Betina yang Diberi Suplemen Serbuk Kunyit (Curcuma longa L.) Secara Oral
}

\section{Reproductive System of Parakeets (Melopsittacus undulatus) Male and Female given Turmeric Powder (Curcuma longa L.) Orally}

\author{
Isfihana Dwi Rukmana ${ }^{1 *}$, Tyas Rini Saraswati ${ }^{2}$, Silvana Tana ${ }^{2}$ \\ ${ }^{1}$ Mahasiswa Program Studi Biologi, Departemen Biologi, Fakultas Sains dan Matemetika, \\ Universitas Diponegoro \\ ${ }^{2}$ Departemen Biologi, Fakultas Sains dan Matemetika, Universitas Diponegoro \\ Jl. Prof. Soedarto, SH Tembalang Semarang \\ *Email : hanaisfi@gmail.com
}

Diterima 31 Desember 2018 / Disetujui 21 Januari 2019

\begin{abstract}
ABSTRAK
Penelitian ini bertujuan untuk mengetahui pengaruh pemberian suplemen serbuk kunyit (Curcuma longa L.)secara oral terhadap sistem reproduksi parkit (Melopsittacus undulatus) jantan dan betina. Data dianalisis menggunakan Uji T. Hewan uji yang digunakan pada penelitian ini adalah 20 parkit umur 4 bulan yang terdiri dari 10 parkit jantan dan 10 parkit betina, masing-masing dibagi menjadi 2 kelompok. Kelompok 1 terdiri dari parkit jantan yang tidak diberi perlakuan (J0) dan parkit jantan yang diberi perlakuan suplemen serbuk kunyit (J1), kelompok 2 terdiri dari parkit betina yang tidak diberi perlakuan (B0) dan parkit betina yang diberi perlakuan suplemen serbuk kunyit (B1). Variabel yang diamati untuk parkit jantan adalah bobot testis dan panjang saluran reproduksi, sedangkan variabel yang diamati untuk parkit betina adalah bobot ovarium, bobot uterus, panjang saluran reproduksi dan bobot saluran reproduksi. Hasil penelitian menunjukan bahwa suplemen serbuk kunyit $35 \mathrm{mg} / \mathrm{ekor} /$ hariyang diberikan secara oral pada parkit jantan dapat meningkatkan bobot testis, akan tetapi tidak berpengaruh terhadap panjang saluran reproduksi parkit jantan dan untuk parkit betina dapat meningkatkan bobot ovarium, bobot uterus, panjang saluran reproduksi, dan bobot saluran reproduksi pada parkit betina. Kesimpulan menunjukkan bahwa pemberian serbuk kunyit secara oral mampu memacu proses reproduksi pada parkit jantan dan parkit betina.
\end{abstract}

Kata kunci: testis, ovarium, burung paruh bengkok, kunyit

\begin{abstract}
The aim of this research was to know the effect of giving turmeric powder (Curcuma longa L.) orally to male and female parakeet reproduction system (Melopsittacus undulatus). Data were analyzed using T Test. The test animals used in this study were 20 parakeets aged 4 months consisting of 10 male parakeets and 10 female parakeets, each divided into 2 groups.Group 1 consisting of unadjusted male parakeet (J0) and male parakeet treated with turmeric powder supplement (J1), group 2 consisting of unadjusted female parakeet (B0) and female parakeet treated with turmeric powder supplement (B1).The variable observed for male parakeets is the testicular weight and length of the reproductive tract, whereas the variables observed for female parakeets are ovary weight, uterine weight, reproductive tract length and reproductive tract weights. The results showed that supplement turmeric powder $35 \mathrm{mg} /$ head / day given orally on male parakeet can increase testicular weight, but does not affect the length of the male parakeet reproductive tract and for female parakeets can increase ovarian weight, uterine weight, reproductive tract length, and reproductive tract weights in female parakeets. The conclusion indicates that giving of turmeric powder orally can stimulate reproduction process on male parakeet and female parakeet.
\end{abstract}

Keywords: testicular,ovarian, bird's hooked beak, turmeric 


\section{PENDAHULUAN}

Indonesia merupakan salah satu daerah tropis yang mempunyai kekayaan alami, baik flora maupun fauna yang melimpah, penyumbang terbesar dalam daftar spesies yang terancam punah dan pengeksport hampir $80 \%$ satwa burung paruh bengkok terbesar di Asia. Terdapat 17\% dari total jenis burung di dunia, 76 jenis adalah burung paruh bengkok. Parkit merupakan salah satu jenis burung paruh bengkok yang memiliki keindahan warna bulu dan sifatnya atraktif (Dhaemojono, 1996). Burung parkit mudah beradaptasi dengan lingkungan. Pemeliharaan yang mengarah pada breeding memerlukan proses pemilihan yang teliti dan terencana terhadap parkit yang akan dibiakkan. Keberhasilan reproduksi merupakan kunci utama dari usaha peternakan.Usaha peternakan burung parkit masih secara tradisional dengan pemberian pakan berupa pelet tanpa penambahan suplemen yang berfungsi untuk memperbaiki sistem reproduksi. Hal inilah yang menjadi salah satu faktor yang dapat mempengaruhi reproduksi burung parkit.

Pemberian suplemen tambahan yang baik pada burung parkit tentunya akan meningkatkan produktivitas reproduksi. PHPA/BirdLife (1998) mengemukakan bahwa, langkanya burung parkit di alam disebabkan oleh kerusakan habitat (50\%), tekanan gabungan antara perburuan dan kerusakan habitat $(10 \%)$, perburuan $(5 \%)$, perdagangan $(3 \%)$, habitat yang sempit disertai populasi yang rendah (16\%), dan sebab lain yang tidak diketahui (16\%). Berdasarkan International Union for Conservation of Nature and Natural Resources (IUCN), burung parkit termasuk dalam status Least Concern(spesies yang telah dievaluasi namun tidak masuk ke dalam kategori manapun) dan produktifitasnya cenderung turun. Salah satu suplemen tambahan yang baik diberikan kepada burung parkit adalah suplemen yang berasal dari bahan herbal. Kunyit merupakan contoh bahan herbal yang dapat digunakan sebagai suplemen tambahan alternatif untuk meningkatkan sistem reproduksi burung parkit jantan dan betina karena kunyit mengandung senyawa aktif kurkuminoid yang berfungsi sebagai hepatoprotektor, antihipertensi, dan antibakteri
(Yarru et al., 2009), sehingga berperan untuk meningkatkan kemampuan reproduksi.

Sistem reproduksi jantan dapat berkembang dengan baik setelah pemberian suplemen serbuk kunyit dalam menghasilkan spermatozoa. Hasil penelitian lanjutan Agustina dkk, (2009), membuktikan bahwa ekstrak ramuan herbal kunyit mengandung berbagai zat bioaktif yang dapat memperbaiki metabolisme dan performa fisiologis pada reproduksi jantan sehingga akan mempengaruhi ukuran testis, bobot testis, dan proses spermatogenesis. Kunyit (Curcuma longa L.) mengandung fitoestrogen yang dapat mengikat reseptor estrogen (Saraswati et al., 2013a)

Pemberian serbuk kunyit dengan dosis sebanyak $54 \mathrm{mg} / \mathrm{ekor} / \mathrm{hari}$ belum maksimal, sehingga ditingkatkan menjadi $108 \mathrm{mg} / \mathrm{ekor} / \mathrm{hari}$ yang dapat meningkatkan produktifitas puyuh (Saraswati, 2013) Hal tersebut dapat dilihat dari serbuk kunyit mengandung kurkumin sebanyak $7,97 \%$ dan fitoestrogen yang bekerja sinergis dalam perbaikan fungsi hati sehingga sintesis vitelogenin meningkat (Saraswati et al., 2013b). Berdasarkan penelitian tersebut diketahui bobot tubuh puyuh 90 $\mathrm{g}$ dengan dosis pemberian serbuk kunyit sebanyak $108 \mathrm{mg}$, sehingga untuk bobot tubuh burung parkit $30 \mathrm{~g}$ maka dosis pemberian serbuk kunyit sebanyak $35 \mathrm{mg} / /$ hari untuk 1 pasang sebelum masak kelamin. Berdasarkan uraian yang telah disebutkan, maka perlu dilakukan penelitian mengenai sistem reproduksi parkit jantan dan betina yang diberi suplemen serbuk kunyit secara oral.

Tujuan dari penelitian ini adalah menganalisis bobot dan ukuran sistem reproduksi parkit jantan dan betina yang diberi suplemen serbuk knyit secara oral.

\section{METODE PENELITIAN}

Penelitian ini dilaksanakan selama empat bulan di Laboratorium Biologi Struktur dan Fungsi Hewan Departemen Biologi Universitas Diponegoro Semarang. Bahan yang digunakan dalam penelitian ini yaitu pakan (terdiri dari pakan jagung, pelet putih, dan pelet merah setiap hari diganti), serbuk kunyit $35 \mathrm{mg} / \mathrm{hari}$, kapur ajaib, air minum (25 $\mathrm{ml} /$ hari), air hangat ( $3 \mathrm{ml} /$ hari untuk menyeduh serbuk kurkumin) dan burung parkit umur 4 bulan 
sebanyak 20 ekor.

\section{Persiapan kandang}

Kandang yang digunakan memiliki ukuran panjang $36,5 \mathrm{~cm}$ dengan lebar $25 \mathrm{~cm}$ berbentuk persegi panjang dan dibuat dari bahan besi dengan alas jaring kawat ukuran kecil dilapisi dengan papan kayu sesuai lebar kandang, papan kayu diberi alas koran agar mudah membersihkan kotoran, kemudian letakkan tempat minum dan tempat makan di dalam kandang. Pintu kandang diberi kawat agar tetap kuat dan aman. Kandang di beri kapur ajaib agar terhindar dari semut.

\section{Pembedaan Jenis Kelamin Untuk Dipasangkan}

Membedakan jenis kelamin pada burung parkit dapat dilakukan dengan cara melihat warna cere (warna hidung pada burung) yang terletak di bagian atas paruh. Parkit jantan memiliki cere berwarna biru, sedangkan parkit betina memiliki cere berwarna putih, coklat muda, atau krem. Setelah proses pembedaan jenis kelamin selesai, kemudian burung parkit dipasangkan dan dimasukkan ke dalam kandang.

\section{Proses Aklimasi Hewan Uji Ke Dalam Kandang}

Burung parkit usia 4 bulan sebanyak 20 ekor dimasukan ke dalam 10 kandang secara berpasangan. Tujuan peletakkan pada 10 kandang secara berpasangan adalah untuk memudahkan perlakuan dan pengamatan sistem reproduksinya. Sebelum parkit diamati, parkit harus diaklimasi selama 1 minggu.

\section{Persiapan Stok Serbuk Kunyit}

Penyiapan stok serbuk kunyit dilakukan dengan cara menyediakan serbuk kunyit sebanyak $12 \mathrm{~g}$ untuk 30 hari. Serbuk kunyit ditimbang sebanyak $35 \mathrm{mg}$ sampai $12 \mathrm{~g}$ serbuk kunyit habis lalu dibungkus menggunakan kertas. Stok serbuk kunyit disimpan ke dalam plastik untuk memudahkan pemberian perlakuan pada parkit.

\section{Pemberian Pakan dan Minum}

Pembuatan pakan mix dengan cara mencampur $1 \mathrm{~kg}$ millet putih ditambah $1 \mathrm{~kg}$ millet merah dan $1 \mathrm{~kg}$ jagung halus, kemudian menimbang pakan mix sebanyak $30 \mathrm{~g} /$ hari untuk 1 pasang parkit. Pemberian minum sebanyak $25 \mathrm{ml} /$ hari untuk 1 pasang parkit.Pakan dan minum ditelakkan ke dalam kandang.

\section{Pemberian Perlakuan}

Pemberian perlakuan dilakukan satu minggu seletah proses aklimasi dilaksanakan. Pemberian perlakuan dengan cara mengambil 1 bungkus dari stok (35 mg) yang sudah dibuat, lalu dilarutkan kedalam $3 \mathrm{ml}$ air hangat dan akan diperoleh serbuk kunyit cair sebanyak 0,2 $\mathrm{ml} /$ ekor/hari. Cara pemberian perlakuan adalah secara oral menggunakan spuit. Pemberian perlakuan dilakukan selama 30 hari.

\section{Pemeliharaan burung parkit}

Pemeliharaan burung parkit dilakukan dengan memperhatikan jenis pakan yang diberikan dan kebersihan kandang. Pakan terdiri dari jagung, millet putih, dan millet merah dengan takaran 1:1:1. Dinding kandang diberi kapur ajaib secara merata agar terhindar dari semut. Cara membersihkan kandang dengan mengganti koran yang melapisi bagian bawah kandang, lalu membersihkan sisa kotoran pada bagian alas kandang dan dinding kandang. Kandang dan lantai tempat penelitian dibersihkan lalu disemprot dengan disinfektan setiap hari.

\section{Pengukuran Suhu dan Kelembaban}

Pengukuran suhu dan kelembaban dilakukan untuk mengetahui kondisi lingkungan yang cocok pada burung parkit. Pengukuran suhu dilakukan sebanyak 3 kali dalam sehari yaitu pada pagi hari yaitu pukul 07.00, siang hari pada pukul 12.00 dan malam hari pada pukul 00.00 .

\section{Pengambilan Data}

Pengambilan data dilakukan dengan cara melakukan dekapitasi pada burung parkit di akhir 
penelitian, kemudian dilakukan pembedahan dengan menggunakan alat bedah (setting set) dari bagian abdomen bawah untuk diambil organ sistem reproduksinya dan diisolasi. Parkit jantan ditimbang bobot testis dan diukur panjang saluran reproduksi dengan batas pemotongan $0,2 \mathrm{~cm}$ diatas kloaka, sedangkan parkit betina ditimbang bobot ovarium, bobot uterus, bobot saluran reproduksi (infundibulum,magnum, itsmus), dan diukur panjang saluran reproduksi (infundibulum, magnum, itsmus, dan vagina), dengan batas pemotongan 0,1 cm diatas kloaka.

\section{Analisis Data}

Data yang diperoleh dari penelitian sistem reproduksi parkit jantan dan betina dianalisis menggunakan Uji $\mathrm{T}$ dan proses pengolahan data menggunakan Software SPSS Versi 16.

\section{HASIL DAN PEMBAHASAN}

Hasil analisis dengan Uji $\mathrm{T}$ pengaruh pemberian suplemen serbuk kunyit secara oral terhadap bobot testis parkit jantan (Tabel 1) menunjukkan hasil yang berbeda nyata $(\mathrm{P}<0.05)$. Bobot testis pada parkit yang tidak diberi suplemen serbuk kunyit sebesar 0,11 g, sedangkan bobot testis pada parkit yang diberi suplemen serbuk kunyit $35 \mathrm{mg}$ sebesar $0,16 \mathrm{~g}$ menunjukkan perbedaan yang signifikan. Hasil pengamatan menunjukan bahwa testis yang diberi serbuk kunyit lebih besar dari pada testis yang tidak diberi serbuk kunyit (Gambar 1). Serbuk kunyit dapat meningkatkan perkembangan testis diduga dengan memicu aktivitas spermatogenesis. Spermatogenesis adalah proses pembentukan sel-sel spermatogenik yang terjadi di dalam tubulus seminiferus di bawah kontrol hormon gonadotropin dari hipofisis anterior (Sukmaningsih dkk., 2011). Senyawa aktif dalam ekstrak kunyit mampu menembus sistem barrier sehingga mempengaruhi spermatogenesis (Zenick and Clegg, 1989). Kurkumin pada kunyit mempengaruhi proses spermatozoa dengan cara meningkatkan proses proliferasi sel (perbanyakan sel) baik secara mitosis maupun meiosis, sehingga menyebabkan pertambahan massa sel dengan laju tertentu (Carlson,1988).
Kadar hormon testosteron dalam darah, dan kualitas spermatozoanya merupakan indikator bagi performan reproduki dan produktivitas parkit jantan (Nalbandov,1990), dalam hal ini, kurkumin pada serbuk kunyit yang diberikan dapat meningkatkan kandungan testosterone pada parkit jantan. Stocco et al., (2005),menjelaskan bahwa pemberian serbuk kunyit yang mengandung kurkumin meningkatkan kadar testosterone. Hormon testosteron dan FSH akan bekerja sama dalam pembentukan organ testis dan juga mengatur proses spermatogenesis yang menghasilkan sel-sel spermatogenik (Anwar, 2005; Hartono, 2004).

Hasil analisis dengan Uji $\mathrm{T}$ pemberian suplemen serbuk kunyit secara oral terhadap panjang' saluran reproduksi parkit jantan menunjukkan hasil yang tidak berbeda nyata $(\mathrm{P}>0,05)$. Pemberian serbuk kunyit pada parkit jantan tidak mempengaruhi panjang saluran reproduksi. Panjang saluran reproduksi pada parkit jantan yang tidak diberi suplemen serbuk kunyit sebesar 2,06 cm, sedangkan panjang saluran reproduksi pada parkit jantan yang diberi suplemen serbuk kunyit sebesar 2,10 cm tidak menunjukan perbedaan yang signifikan, hal ini terjadi karena parkit jantan masak kelamin pada umur 4 bulan mungkin belum memasuki masa birahi, namun sudah mempersiapkan sistem reproduksinya jika terjadi proses pembuahan. Menurut Widodo (2002), bahwa burung parkit memasuki masa birahi pada umur 5 bulan yang artinya burung parkit tersebut siap kawin, oleh karena itu pemberian serbuk kunyit belum mempengaruhi panjang saluran reproduksi karena parkit jantan pada penelitian masih berusia 4 bulan.

Nadia et al., (2008), menjelaskan bahwa kunyit mengandung kurkumin yang bekerja pada saluran reproduksi untuk meningkatkan pertumbuhan lapisan penyusun dinding saluran reproduksi dan sel-sel kelenjar pada saluran reproduksi berkembang baik. Perkembangan saluran reproduksi parkit jantan berhubungan dengan perkembangan spermatogenesis, meskipun pemberian serbuk kunyit secara oral meningkatkan bobot testis namun belum mempengaruhi panjang saluran reproduksi parkit jantan, akan tetapi serbuk kunyit mampu memacu perkembangan saluran 
reproduksi jantan yang belum masak kelamin menjadi masak kelamin untuk menstimulasi perkembangan fungsional saluran reproduksi.

Hasil analisis dengan $\mathrm{Uji} T$ pengaruh pemberian suplemen serbuk kunyit secara oral terhadap bobot ovarium, bobot uterus, bobot saluran reproduksi, dan panjang saluran reproduksi parkit betina seperti pada Tabel 2. Hasil analisis dengan Uji $\mathrm{T}$ pengaruh pemberian suplemen serbuk kunyit secara oral terhadap bobot ovarium menunjukkan hasil yang berbeda nyata $(\mathrm{P}<0,05)$. Bobot ovarium yang tidak diberi suplemen serbuk kunyit sebesar $0,015 \mathrm{~g}$, sedangkan bobot ovarium yang diberi suplemen serbuk kunyit sebesar 0,052 g menunjukkan perbedaan yang signifikan. Parkit yang belum dewasa memiliki ovarium yang belum berkembang sempurna. Hartanto (2010), mengatakan bahwa pertumbuahan kelenjar telur dirangsang oleh Follicle Stimulating Hormon (FSH) yang dihasilkan oleh kelenjar pituitari anterior. Hal ini menunjukkan bahwa suplemen serbuk kunyit mampu meningkatkan perkembangan ovarium parkit betina. Bobot ovarium sangat dipengaruhi oleh jumlah atau banyaknya folikel ovarium. Semakin banyak folikel dan semakin besar diameter folikel maka akan meningkatkan bobot ovarium. Hasil pengamatan terhadap folikel ovarium menunjukkan bahwa meskipun serbuk kunyit mampu meningkatkan perkembangan ovarium pada parkit betina, tetapi baru terbentuk pertumbuhan folikel non hirarki dan belum terbentuk hirarki folikel (Gambar 2), hal ini terjadi dimungkinkan karena vitelogenin yang terbentuk pada awal masak kelamin belum cukup, sehingga distribusi vitelogenin dari hati ke ovarium belum maksimal dan parkit betina masak kelamin umur 4 bulan yang digunakan dalam penelitian belum memasuki dewasa kelamin, namun sudah mulai mempersiapkan sistem reproduksi

Tabel 1. Hasil Analisis Pengaruh Pemberian Suplemen Serbuk Kunyit Secara Oral Terhadap Sistem Reproduksi Parkit (Melopsittacus undulatus) Jantan.

\begin{tabular}{|c|c|c|c|c|c|c|}
\hline \multirow[t]{2}{*}{ Parameter } & \multirow{2}{*}{$\begin{array}{c}\text { Jumlah } \\
\text { perlakuan }\end{array}$} & \multicolumn{2}{|c|}{ Rerata } & \multirow[t]{2}{*}{ SD } & \multirow[t]{2}{*}{ t Hitung } & \multirow[t]{2}{*}{ T-test } \\
\hline & & J0 & $\mathrm{J} 1$ & & & \\
\hline Bobot Testis (g) & 5 & 0,11 & 0,16 & 0,016 & $-6,124$ & $0,009 *$ \\
\hline $\begin{array}{l}\text { Panjang saluran reproduksi } \\
(\mathrm{cm})\end{array}$ & 5 & 2,06 & 2,10 & 0,409 & $-0,218$ & 0,838 \\
\hline
\end{tabular}

Keterangan : *memiliki perbedaan signifikan dengan $\mathrm{P}<0,05$, J0: Parkit jantan tanpa pemberian suplemen serbuk kunyit, J1: Parkit jantan dengan pemberian suplemen serbuk kunyit $35 \mathrm{mg}$
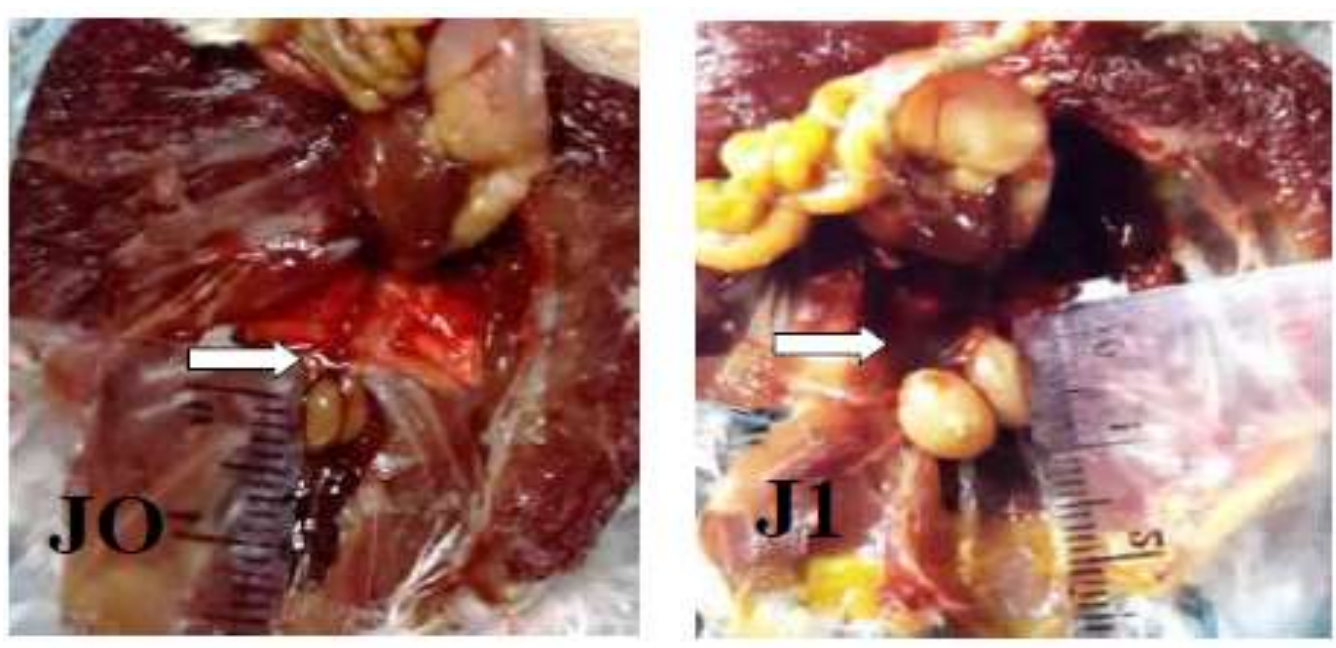

Gambar 1. Testis Parkit Jantan 
Serbuk kunyit mengandung fitoestrogen sebesar 7,97\% (Saraswati et al., 2013b). Fitoestrogen adalah senyawa alami tanaman yang mempunyai kesamaan struktur dengan estrogen sehingga dapat mengikat reseptor estrogen (Turner et al. 2007). Fitoestrogen pada serbuk kunyit mampu berikatan dengan reseptor estrogen pada sel theca dan granulose untuk memacu pertumbuhan folikel ovarium (Nadia et al. 2008).

Hasil analisis dengan Uji $\mathrm{T}$ pengaruh pemberian suplemen serbuk kunyit secara oral terhadap bobot uterus menunjukkan hasil yang berbeda nyata $(\mathrm{P}<0,05)$. Bobot uterus yang tidak diberi suplemen serbuk kunyit sebesar 0,025 g, sedangkan bobot uterus yang diberi suplemen serbuk kunyit sebesar 0,050 g menunjukkan perbedaan yang signifikan. Hal ini menunjukkan bahwa suplemen serbuk kunyit mampu meningkatkan perkembangan uterus parkit betina. Kunyit mengandung fitoestrogen yang dapat meningkatkan perkembangan sel pada uterus. Ravindar dkk., (2007), berpendapat bahwa fitoestrogen pada kunyit meningkatkan jumlah folikel yang berkembang. Seiring dengan perkembangan folikel, estrogen akan mulai disintesis dan disekresi. Lewis \& Moris (2006), menjelaskan bahwa serbuk kunyit berfungsi dalam peningkatan konsentrasi estrogen akan merangsang perkembangan uterus dalam rangka peningkatan absorbsi kalsium yang nantinya dibutuhkan dalam persiapan pembentukan kerabang telur di uterus, oleh karena itu terjadi peningkatan bobot uterus setelah pemberian serbuk kunyit.

Tabel 2. Hasil Analisis Pengaruh Pemberian Suplemen Serbuk Kunyit Secara Oral Terhadap Sistem Reproduksi Parkit (Melopsittacus undulatus) Betina

\begin{tabular}{lcccccc}
\hline Parameter & Jumlah & \multicolumn{2}{c}{ Rerata } & SD & t Hitung & P T-test \\
\cline { 3 - 4 } & Perlakuan & B0 & B1 & & & \\
\hline Bobot Ovarium (g) & 5 & 0,015 & 0,052 & 0.017 & $-4,392$ & $0,022^{*}$ \\
$\begin{array}{l}\text { Bobot Uterus (g) } \\
\text { Bobot Saluran Reproduksin }\end{array}$ & 5 & 0,025 & 0,050 & 0,005 & $-8,660$ & $0,003^{*}$ \\
$\begin{array}{l}\text { (g) } \\
\begin{array}{l}\text { Panjang Saluran Reproduksi } \\
(\mathrm{cm})\end{array}\end{array}$ & 5 & 0,026 & 0,046 & 0,007 & $-6,325$ & $0,003^{*}$ \\
\hline
\end{tabular}

Keterangan : * memiliki perbedaan signifikan dengan $\mathrm{P}<0,05$, B0: Parkit betina tanpa pemberian suplemen serbuk kunyit, B1: Parkit betina dengan pemberian suplemen serbuk kunyit $35 \mathrm{mg}$
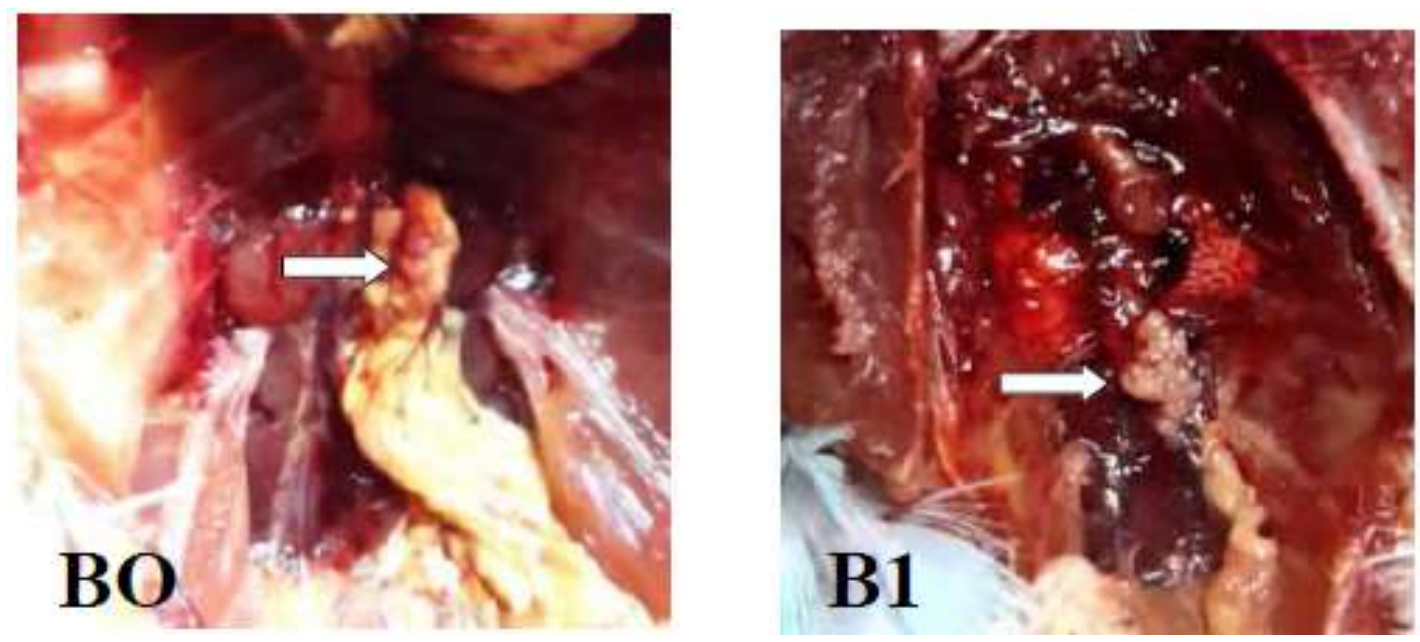

Gambar 2. Folikel parkit betina 
Hasil analisis dengan Uji $\mathrm{T}$ pengaruh pemberian suplemen serbuk kunyit secara oral terhadap panjang saluran reproduksi menunjukkan hasil yang berbeda nyata $(\mathrm{P}<0,05)$. Panjang saluran reproduksi yang tidak diberi suplemen serbuk kunyit sebesar 2,1 cm, sedangkan panjang saluran reproduksi yang diberi suplemen serbuk kunyit sebesar 2,56 cm menunjukkan perbedaan yang signifikan, hal ini menunjukkan bahwa suplemen serbuk kunyit mampu meningkatkan perkembangan saluran reproduksi parkit betina. Saluran reproduksi betina terdiri dari infundibulum, magnum, isthmus, uterus, dan vagina.Serbuk kunyit mengandung fitoestrogen yang berperan dalam pertumbuhan selsel saluran reproduksi. Saraswati et al., (2014), menjelaskan bahwa pemberian serbuk kunyit dapat memacu perkembangan saluran reproduksi. Palmitter (1972), mengatakan bahwa peningkatan konsentrasi estrogen setelah pemberian suplemen kunyit dapat menstimulasi perkembangan fungsional saluran reproduksi (oviduk), sehingga terjadi peningkatan panjang saluran reproduksi yang berfungsi untuk persiapan pembentukan telur. Ukuran oviduk mengalami perubahan sejalan dengan aktivitas reproduksi (Suprijatna, 2005). Serbuk kunyit mengandung fitoestrogen yang berperan sama seperti estrogen. Palmitter (1972), mengatakan bahwa peningkatan konsentrasi estrogen setelah pemberian suplemen kunyit dapat menstimulasi perkembangan fungsional saluran reproduksi (oviduk), sehingga terjadi peningkatan panjang saluran reproduksi.

Banyaknya folikel yang terbentuk dan berkembang setelah penambahan serbuk kunyit. Pertumbuhan folikel ovarium dan sekresi estrogen dikendalikan oleh hormon gonadotropin. Hormon gonadotropin yang dihasilkan oleh hipofisis anterior terdiri atas folicle stimulating hormone (FSH) dan Luteinizing hormone ( $\mathrm{LH})$. Hormon FSH akan mempengaruhi pertumbuhan folikel. Folikel yang tumbuh akan memicu ovarium untuk mensekresikan estrogen. Kehadiran estrogen akan menginisiasi pertumbuhan dan perkembangan oviduk (Kasiyati, 2009), sehingga terjadi pertambahan massa dan ukuran saluran reproduksi parkit betina.

Hasil analisis dengan Uji $\mathrm{T}$ pengaruh pemberian suplemen serbuk kunyit secara oral terhadap bobot saluran reproduksi menunjukkan hasil yang berbeda nyata $(\mathrm{P}<0,05)$. Pemberian suplemen serbuk kunyit pada parkit betina dapat meningkatkan bobot saluran reproduksi. Bobot saluran reproduksi yang tidak diberi suplemen serbuk kunyit sebesar 0,026 g, sedangkan bobot saluran reproduksi yang diberi suplemen serbuk kunyit sebesar 0,046 g menunjukkan perbedaan yang signifikan. Seiring dengan peningkatan panjang saluran reproduksi parkit betina, maka menyebabkan terjadinya peningkatkan bobot saluran reproduksi parkit betina setelah pemberian suplemen serbuk kunyit. Biswas et al. (2010), mengatakan bahwa setelah masak kelamin, sekresi estrogen oleh sel teka dan sel granulose meningkat, selanjutnya estrogen akan merangsang perkembangan saluran reproduksi. Semakin banyak folikel yang terbentuk menyebabkan saluran reproduksi aktif menstimulasi pertumbuhan sel dan jaringannya, sehingga bobot dan panjang saluran reproduksi meningkat, setelah memasuki umur masak kelamin akan terjadi peningkatan aktivitas saluran reproduksi diikuti dengan peningkatan secara progresif bobot dan panjang saluran reproduksi.

\section{KESIMPULAN}

Hasil penelitian menunjukkan suplemen serbuk kunyit $35 \mathrm{mg}$ yang diberikan secara oral dapat meningkatkan bobot testis, akan tetapi tidak berpengaruh terhadap panjang saluran reproduksi pada parkit jantan. Suplemen serbuk kunyit $35 \mathrm{mg}$ yang diberikan secara oral juga dapat meningkatkan bobot ovarium, bobot utetus, panjang saluran reproduksi, dan bobot saluran reproduksi pada parkit betina, sehingga menunjukkan bahwa pemberian serbuk kunyit secara oral mampu memacu proses reproduksi pada parkit jantan dan parkit betina yang belum dewasa kelamin menjadi dewasa kelamin.

\section{DAFTAR PUSTAKA}

Anwar, R. 2005. Sintesis, Fungsi dan Interpretasi Pemeriksaan Hormon Reproduksi. FK UNPAD. Bandung.

Biswas A, Mohan J,Venkata K, Sastry H. 2010. Age-Dependent Variation in Hormonal 
Concentration and Biochemical Constituents in Blood Plasma of Indian Native Fowl.Vet Med Int: 737292. doi: $10.4061 / 2010 / 737292$

Carlson, B.M., 1988. Patten's Foundation of Embryology, 5th Ed. Mc Graw HillBook Co. New York.

Hartanto. 2010. Pengaruh Ranggas Paksa (Forced Molting) Metode Puasa Dan Suplementasi Tepung Bekicot (Achatina fulica) Pada Ransum Terhdap Bobot Ovarium Dan Pertumbuhan Folikel Yolk Ayam Arab (Gallus turcicus). Skripsi. Malang : UIN Malang

Hartono, T. 2004. Permasalahan Puyuh dan Solusinya. Penebar Swadaya. Jakarta

Kasiyati.2009. Umur Masak Kelamin dan Kadar Estrogen Puyuh (Coturnix coturnix japonica) Setelah Pemeberian Cahaya Monokromatik.Tesis. Institut Pertanian Bogor

Lewis P, dan Morris T. 2006. Poultry Lighting;The Theory and Practice. Hamphire. UK: Northcort

Nalbandov.A.V.1990. Fisiologi Reproduksi Pada Mamalia dan Unggas. Jakarta. UI Press.

Palmiter RD. 1972. Regulation of protein synthesis in chick oviduct: independent regulation of ovalbumin, conalbumin, ovomucoid and lysoyme induction. J Biol Chem 247:64506461

Perlindungan Hutan dan Pelestarian Alam (PHPA)/BirdLife. 1998. Rencana Pemulihan Kakatua Kecil Jambul Kuning. PHPA/BirdLife InternationalIP.

Ravindar PN, Babu KN, Sivaraman K. 2007. Turmeric.The Genus Curcuma.CRC Press. London, New York.

Saraswati T.R., Manalu W., Ekastuti D.R., and Nastiti K. 2013b. The Role of Turmeric Powder in Lipid Metabolism and the Effect on The Quality of The First Quail's Egg.
The Journal of The Indonesian tropical Animal Agriculture.38 (2).

Saraswati, T. R. 2013. Optimalisasi Kondisi Fisiologis Puyuh Jepang (Coturnix coturnix japonica) dengan Suplementasi Serbuk Kunyit (Curcuma longa).Disertasi. Progam Doktor Institut Pertanian Bogor, Bogor

Saraswati, T.R., W. Manalu., D.R. Ekastuti.,and N.Kusumorini. 2013a. Increase Egg Production of Japanese Quail (Coturnix japonica) by Improving Liver Function Through Turmeric Powder Supplementation. International Journal of poultry Science 12(10):601-614

Saraswati T.R, Manalu W, Ekastuti D.R, Nastiti K. 2014. Effect of Turmeric Powder to Estriol and Progesterone Hormone Profile of Laying Hens During One Cycle of Ovulation. International Journal of Poultry Science 13 (9): 504-50.

Stocco, D.M., Wang ,X., Jo, Y., and Manna, P.R. 2005. Multiple Signaling Pathways Regulating Steroidogenesis and Steroidogenic Acute Regulatory Protein Expression: More Complicated than We Thought. Mol Endocrinol .19(11):26472659.

Turner J.V, Kustrin A.S, Glass B.D. 2007. Molecular Aspects of Phytoestrogen Selective Binding at Estrogen Receptors.J Pharm Sci 96 (8): 1879- 1885.

Yarru, L.P, Settivari, R.S, Gowda, N.K.S, Antoniou, E., Ledoux, D.R., and Rottinghaus, G.E.2009. Effects of turmeric (Curcuma longa) on the expression of hepatic genes associated with biotransformation, antioxidant, and immune systems in broiler chicks fed aflatoxin. Poultry Science.8(12): 2620-2627.

Zenic, H. and E.D. Clegg, 1989. Assesment of Reproductive Toxicology : A Risk Assesment Approach. In : Principles and Method of Toxicology. 2 Ed.Raven Press, Ltd. New York 